Relations industrielles

Industrial Relations

\title{
Katz, Harry C. and Owen Darbishire, Converging Divergences: Worldwide Changes in Employment Systems
}

\section{Nick Wailes}

Volume 55, numéro 3, 2000

URI : https://id.erudit.org/iderudit/051337ar

DOI : https://doi.org/10.7202/051337ar

Aller au sommaire du numéro

Éditeur(s)

Département des relations industrielles de l'Université Laval

ISSN

0034-379X (imprimé)

1703-8138 (numérique)

Découvrir la revue

Citer ce compte rendu

Wailes, N. (2000). Compte rendu de [Katz, Harry C. and Owen Darbishire,

Converging Divergences: Worldwide Changes in Employment Systems]. Relations industrielles / Industrial Relations, 55(3), 540-543.

https://doi.org/10.7202/051337ar

Tous droits réservés @ C Département des relations industrielles de l'Université Laval, 2000
Ce document est protégé par la loi sur le droit d'auteur. L’utilisation des services d'Érudit (y compris la reproduction) est assujettie à sa politique d'utilisation que vous pouvez consulter en ligne.

https://apropos.erudit.org/fr/usagers/politique-dutilisation/ 
in-depth, and entertaining guide to combining qualitative and quantitative approaches. Their work offers important insights for those of us working in a multi-disciplinary applied field such as Industrial Relations.

No strangers to battle themselves, Tashakkori and Teddlie begin with an informative discussion of the paradigms and politics of research in the (broadly defined) social and behavioural sciences. Beginning in the $50 \mathrm{~s}$, they trace three stages of the "paradigm wars" between "positivists" and "constructivists", and analyze the differences in logic, the role of values, epistemology, ontology, and the nature of causal linkages. They then discuss the benefits of a pragmatic approach, and strongly endorse the view that research questions drive decisions about methodology. To this they add an extensive analysis of a variety of designs, and data-gathering and dataanalysis techniques, and find common ground in the necessity of ruling out alternative explanations. In itself, this part of the book would be an important addition to most research methods courses.

As well as this informed overview of research methods, a significant contribution of the work is Tashakkori and Teddlie's conceptual model - a well- reasoned and logically exhaustive typology of mixed models and mixed methods They further add a guide and instructions for each type of methodology mix, complete with examples of how to benefit (but only where it actually produces benefits!) from mixed methodology approaches to design, sampling, data collection, and data analysis.

Gratefully, the book is indexed (many in the Sage series are not). The authors write clearly, chapters are introduced and summarized, and the authors suggest along the way who might want to skip what.

I must point out that Tashakkori and Teddlie are not zealots, interested in converting us all to the one true way. At heart, and throughout the book, they are pragmatists whose main concern is to get the research done effectively and validly. If mixed methods do not work better at some stage of the research, don't use them. The benefit for all of us is their patient demonstration, with instruction and examples, that mixed methodology often does work better. Industrial relations will be the better for it.

\section{JoHN KERVIN University of Toronto}

\section{Converging Divergences: Worldwide Changes in Employment Systems}

by Harry C. Katz and Owen Darbishire, Ithaca, N.Y.: ILR Press/Cornell University Press, 2000, 321 p., ISBN: 0-8014-3674-5.

There has been something of a renaissance in comparative industrial relations scholarship. Converging Divergences is the latest in a long line of books which attempts to map global changes in industrial relations. The basic argument of Converging Divergences can be summarized as follows. The authors argue that there are a common set of changes taking place in employment relations in developed economies (like decentralization of bargaining and individualization of relations between employers and employees). They attribute particular importance to a shared increase in the diversity of employment patterns within countries which otherwise differ along a number of dimensions (the U.S., the U.K., Australia, Germany, Sweden, Japan, and Italy). They call this "convergence on divergence'. They claim that this convergent divergence is characterized by the spread of four employment relations patterns - a low wage pattern, an HRM pattern, a Japanese oriented model and 
a joint team based pattern - across each of the countries. However, while they identify convergence on divergence, they also argue that institutional differences across the countries result in different distributions of the various employment patterns in the different countries. They illustrate this by focussing in depth on changes in employment patterns in two industries (telecommunications and autos) within each country. The basic argument of Converging Divergences is laid out in Chapter 1. Chapters 2 through 6 present countrylevel case studies which provide evidence to support the argument. Chapter 7 reiterates the argument and draws out implications for union strategy.

I will not dwell on the empirical content of the book other than to simply note that it seems to reproduce data that has already been extensively published in books and articles associated with the international motor vehicle project and with the MIT project. The authors have done a good job of updating some of this information, rendering complex institutional details understandable and presenting the information from country case studies in broadly similar fashion. All of these are necessary, but not sufficient, conditions for more thoroughgoing comparative analysis.

Converging Divergences is more interesting in what it says about the relative theoretical and methodological sophistication of contemporary comparative industrial relations scholarship. Katz and Darbishire provide some evidence of increased variation in employment conditions across a range of countries. They also present evidence to suggest that while there are similar tendencies in each of their cases, institutional differences across the cases result in different distributions of the various employment patterns within the industries upon which they focus. However, this is not theory; rather it is an empirical pattern which requires explanation.
How do Katz and Darbishire explain the empirical regularity they identify and from which the Converging Divergences title is derived? What theory do they advance to account for these converging divergences? I would argue that there is no systematic attempt to explain the apparent convergence on divergence across different countries. Furthermore, there is no clearly articulated explanation of the factors which help determine when institutions matter and when they do not in shaping the pattern of employment relations. In places the pressures that have led to convergence on divergence are treated as largely unimportant or sui genesis. For example, "Thus whatever the sources of economic pressures, variation in the processes and outcomes of employment relations have increased in all seven countries" (p. 4). In this regard Converging Divergences is a step backwards from the convergence hypothesis advanced by Kerr, Dunlop, Harbison and Myers in Industrialism and Industrial Man. At least, Kerr et al. identified the "whatever" (industrialism) that they claimed was causing convergence. Darbishire and Katz offer no clear causal framework within which to understand their data.

This is not to argue that there are no causal statements in Converging Divergences, but rather that they are not presented in an explicit or systematic fashion nor are they tested in any way through comparison. Most of the causal statements about the pressures for change in employment relations are embedded in the country case studies. Perhaps the clearest attempt to provide reasons for increased diversity of employment practices is in the U.S. chapter (Chapter 2) where the authors essentially summarize the arguments put forward by Kochan, Katz and McKersie about the strategic choices by management. On one reading, the rest of the book can be seen as an attempt to generalize this strategic choice model. If this was the authors' intention, it should have been made more explicit. 
Converging Divergences illustrates another limitation of contemporary comparative industrial relations scholarship - the tendency to derive typologies inductively. Katz and Darbishire present four employment relation types: low wage, HRM, Japanese oriented and joint team based. These types appear to have been derived descriptively to characterize patterns that are evident in the country case studies, without specifying the underlying dimensions. The authors then use the same case studies to validate the typology. I realize now that this is why I was always taught that a typology is best derived from the specification of underlying dimensions informed by theory.

There are a number of other problems with such an approach. The types may not be mutually exclusive. For example, the failure to identify evidence of the HRM model in Germany (p. 222223) may reflect the fact that the type is really a description of a U.S. manifestation of a more general pattern of employment relations. If this is the case, then it is quite interesting that there is evidence of this pattern outside the U.S. Furthermore, the types may not be independent. For example, it seems reasonable to argue that the development of a Japanese-oriented pattern necessitates the establishment of something like a low wage pattern. One need only look at Japan for evidence of this. After all, less than one third of the Japanese workforce has ever enjoyed the benefits of what Katz and Darbishire characterize as the "Japanese pattern".

While many of the problems in the book relate to the lack of theory, when Katz and Darbishire do try to explicitly employ theoretical constructs these do not necessarily enhance their analysis. The converging divergences hypothesis is based on a reading of Richard Locke's work on Italy. Locke's original argument was that national level institutions were becoming less important for determining patterns of industrial relations and that sub-national institutions were playing a greater role in determining patterns of industrial relations. Katz and Darbishire demonstrate that while there is evidence to suggest greater divergence of industrial relations outcomes within each of their cases (which is consistent with Locke's hypothesis), national level institutions still play a significant role in determining the distribution of these various patterns and therefore national level institutions continue to have an important role in explaining patterns of cross national difference. This would seem to provide evidence to refute Locke's hypothesis and suggests the need for an alternative hypothesis.

In the absence of a theoretical framework, it is hard not to conclude that the empirical pattern that Katz and Darbishire identify is largely an artefact of how they have constructed their research. There are in fact two conflicting research designs operating in this book. The first research design employs the method of agreement. That is, it identifies a shared variation on the dependent variable (relative diversity of employment practices) across countries cases which differ significantly in key areas. What would it take for the cases to exhibit convergence in this framework? The answer is not much. Such an approach potentially masks significant differences between cases, which nonetheless meet the convergence criteria. For example, it is possible to conclude, within this framework, that the U.S. and Sweden share the same pattern of divergence. However there are a lot of important differences between the two countries which are subsequently ignored. It also has consequences for theory development. It suggests that divergence of employment patterns in Sweden and the U.S. needs to be explained by the same factors. No wonder Katz and Darbishire demure from the task of presenting a systematic causal framework.

The second research design extant in Converging Divergences uses the 
method of difference to explain variations on the dependent variable amongst most similar cases. Therefore the authors attempt to identify the factors that account for variations on the dependent variable (the distribution of employment relations patterns) across the same two industries (autos and telecom) in different countries. This design assumes that by matching industries, many of the sources of variation in the distribution of employment patterns between the different countries will be controlled for. The consequence of this research design is that cross-national differences in patterns of the distribution of employment practices within the same industry are attributed to institutional differences between the countries. It is not hard to think of problems with this assumption. For example, Australia has been characterized by systematic under-investment in new plant and technology in the auto sector (as a consequence of the tariff protection regime and the domestic market focus of the industry) and this has an influence on how work is organized in its car factories. When compared with Japan or Germany, this difference in capital intensity and technological sophistication would surely play a role in explaining differences in the distribution of employment practices between the cases, yet the approach Katz and
Darbishire adopt excludes these structural factors from the analysis. All that is left to explain differences in the industry patterns between the cases are institutional differences, which apparently enjoy an almost independent existence.

The consequence of adopting these two research designs, side by side, is that we are left with contradictory, or at the very least confusing, evidence that suggests, on the one hand, that institutions do not matter (because there is evidence of convergence on divergence across countries) and, on the other, that institutions do matter (because there is divergence in the extent of convergent divergence within the different industries). In the absence of a clearly articulated theoretical argument, it would seem reasonable to conclude that this empirical pattern may simply result from the way the research is constructed. For this reason, and the others I have outlined above, I think Converging $\mathrm{Di}$ vergences illustrates both the relative lack of theoretical sophistication in industrial relations and also the underlying problems with theory development in comparative industrial relations research.

Nick WaILeS The University of Sydney

\section{State-Making and Labor Movements : France and the United States, 1876- 1914 \\ par Gerald Friedman, Ithaca, N.Y. : Cornell University Press, 1998, 317 p., ISBN 0-8014-2325-2.}

Comment analyser les différences considérables entre les orientations des mouvements ouvriers et du syndicalisme dans des pays de développement économique comparable? La question demeure, depuis longtemps, l'une des pierres de touche de l'histoire du travail et des relations professionnelles, et donc plus largement de l'histoire économique. Gerald Friedman la reprend à partir d'une analyse comparée des deux cas exemplaires que sont la France et les États-Unis dans la période de fondation des mouvements ouvriers qui se situe au tournant du $\mathrm{XIX}^{\mathrm{e}}$ au $\mathrm{XX}^{\mathrm{e}}$ siècles.

Les analyses traditionnelles se focalisaient soit sur les orientations internes et les débats des mouvements ouvriers et syndicaux, soit sur les formes et rythmes des évolutions économiques des appareils industriels. La thèse qu'il propose prend le contrepied de ces 